\title{
Manajemen Usaha Dan Produksi Pada Usaha Mikro, Kecil Dan Menengah (UMKM) Di Desa Carang Wulung Wonosalam
}

\author{
Abd. Rohim \\ abdulrohim1304@gmail.com \\ Indra Kurniawan \\ adheandra@yahoo.com
}

STIE PGRI Dewantara Jombang

Diserahkan: 12 Maret 2017, Direvisi: 25 Maret 2017, Disetujui: 5 Mei 2017

\begin{abstract}
Abstrak
Kegiatan pendampingan yang dilakukan pada bulan Januari - Maret 2017 di desa Carang Wulung, Wonosalam Jombang ini bertujuan untuk ikut serta membantu pemberdayaan ekonomi masyarakat , khususnya makanan olahan kripik dengan bahan dasar pisang dan talas. Kegiatan ini melibatkan 2 (dua) orang mitra yang memilki kemauan dan bersedia menjadi mitra binaan. Jenis pendampingan meliputi pembinaan di bidang: a) Pelatihan \& Pendampingan Manajemen Usaha, b) Pelatihan \& Pendampingan Packaging, Branding, \& Labelling, c) Pelatihan \& Pendampingan Akses Pemodalan Perbankan, d) Pelatihan \& Pendampingan Pemasaran. Diakhir kegiatan, kedua mitra binaan telah mampu menyerap dan mempraktikkan apa yang telah disampaikan oleh tim pendamping sehingga usaha kedua mitra menjadi lebih baik.
\end{abstract}

Kata Kunci: Pendampingan, makanan olahan, kripik pisang, talas.

\section{Abstract}

The mentoring activity conducted in January - March 2017 in Carang Wulung village, Wonosalam Jombang, is aimed to help the economic empowerment of the community, especially processed chips with basic ingredients of banana and taro. This activity involves 2 (two) partners who have the will and are willing to become partners. Types of mentoring include coaching in the areas of: a) Training \& Assistance of Business Management, b) Training \& Assistance of Packaging, Branding, \& Labeling, c) Training \& Facilitation of Banking Capital Access, d) Training \& Mentoring. At the end of the activity, the two partners have been able to absorb and practice what has been delivered by the counterpart team so that the efforts of both partners to be better.

Keywords: Assistance, processed foods, banana chips, taro.

\section{A. PENDAHULUAN}

\section{Latar Belakang}

Kondisi klasik yang dirasakan oleh penggiat Usaha Mikro, Kecil dan menengah (UMKM) dari waktu ke waktu sudah lazim diketahui antara lain, aspek permodalan, sumberdaya manusia, minimnya jaringan untuk pengembangan bisnis, ini semua merupakan kondisi internal yang dialami oleh UMKM. Sementara itu terdapat permasalahan lain yang secara eksternal diluar kendali UMKM antara lain, tingkat kompetitor, infrastruktur dalam memasarkan produk, dampak pasar bebas (AFTA \& AEC) menjadi beban bagi mereka dalam mengembangkan usaha.

Tidak dapat di pungkiri bahwa usaha kecil, mikro dan menengah merupakan penopang terbesar perekonomian dalam negeri, bagaimana usaha mikro, kecil dan menengah ini memberikan kontribusi angkatan kerja yang artinya mampu mereduksi angka pengangguran, sehingga menekan angka kemiskinan, mampu meningkatkan kesejahteraan dan dapat membangun karakter bangsa melalui pendidikankewirausahaan. Hal ini senada dengan yang diungkapkan oleh Berry (2001) yang menyatakan tiga alasan mendasar Negara berkembang memandang penting keberadaan UMKM, yang pertama adalah kinerja UMKM lebih baik dalam hal menghasilkan tenaga kerja, yang kedua yakni UMKM sering mencapai 
peningkatan produktivitasnya melalui investasi dan perubahan teknologi, dan yang ketiga yaitu diyakini UMKM memiliki keunggulan pada fleksibilitas ketimbang usaha besar.

Kondisi tersebut dibuktikan pada saat krisis pada tahun 1998 yang mengguncang perekonomian dunia tidak terkecuali Indonesia, keberadaan UMKM mampu menopang perekonomian dan tidak goyah diterjang krisis. Karena masyarakat Indonesia menuju industrialisasi, maka kondisi saat krisis sangat memberatkan masyarakat pada umumnya terutama masyarakat perkotaan yang paling besar terkena dampak sosial dan ekonomi (Watterberg, 1999).

Pada saat ini makin menunjukkan tren positif terkait jumlah UMKM yang ada di Indonesia, sehingga diperlukan upaya dan langkah positif dalam meningkatkan eksistensinya. Karena kendala UMKM masih berputar pada aspek teknis produksi, aspek keuangan dan aspek pemasaran. Pada aspek produksi permasalahan yang perlu mendapatkan perhatian adalah bagaimana meningkatkan kapasitas produksi terhadap produk yang dihasilkan, serta bagaimana menjaga kualitas produk tersebut. Konsentrasi pada kedua hal tersebut saja masih perlu penambahan lagi yakni upaya inovasi dan pengembangan produk perlu mendapatkan perhatian yang serius. Apabila perhatian tersebut benar-benar serius dilakukan maka UMKM akan memiliki daya saing (competitive advantage), hal ini bisa dilihat dari data World Economic Forum (WEF) tahun 2003 dalam mengukur daya saing adalah pertama dari sisi makro melalui Growth Competitiveness Index (GCI) Indonesia menempati urutan ke 72 dan ukuran yang kedua menggunakan Business Competitiveness Index (BCI) Indoensia menempati urutan ke 60 dari 102 negara (Primiana, 2009).

Di desa Carangwulung kecamatan Wonosalam, terdapat beberapa penggiat UMKM yang menggeluti usaha makanan olahan kripik berbahan dasar pisang, ketela dan talas. Kapasitas produksi yang dihasilkan masih sangat terbatas, karena aspek penjualannya masih berputar di sekitar desa tersebut saja, sementara bahan baku yang diperlukan sangat banyak tersedia di daerah tersebut.

Desa Carangwulung berada di wilayah kecamatan Wonosalam di kawasan pegunungan Anjasmoro yang memiliki sumberdaya yang melimpah. Mata pencaharian penduduk mayoritas bertani dan berkebun. Kekayaan sumberdaya yang melimpah ini belum dimanfaatkan secara optimal oleh penduduk sekitar, karena memang sumberdaya manusia masih sangat terbatas. Seperti diketahui bahwa kawasan Wonosalam merupakan daerah pegunungan dan masyarakatnya banyak menggeluti usaha mikro. Namun demikian bagaimana upaya meningkatkan kesejahteraan masyarakat tersebut agar lebih berdaya melalui peningkatan usaha mikronya. Salah satunya adalah Desa Carangwulung yang memiliki beberapa produk kripik, susu sapi dan kambing etawa dan lain-lain.

\section{Profil Mitra}

$\mathrm{Bu}$ Ani dan $\mathrm{Bu}$ Nunuk adalah dua dari beberapa pengrajin makanan olahan kripik dengan bahan dasar pisang dan talas yang kita jadikan mitra dalam program ini. Kapasitas produksi yang dihasilkan oleh $\mathrm{Bu}$ Ani dan Bu Nunuk cukup lumayan, tetapi masih banyak diperlukan upaya optimalisasi peningkatan usaha. Berawal dari hasil kegiatan Kuliah Kerja Nyata yang telah tiga tahun dilaksanakan di desa tersebut, dan eksistensi usaha kedua mitra tersebut dari waktu ke waktu belum menunjukkan peningkatan secara maksimal, sehingga menjadi perhatian bagi kami untuk memberikan kontribusi dalam rangka membantu usaha $\mathrm{Bu}$ Ani dan Bu Nunuk.

Potensi usaha yang digeluti mitra sangat baik jika dilihat dari segi bahan baku yang dibutuhkan, karena wilayah Carang wulung adalah berada di lereng pegunungan Anjasmoro yang sangat terhampar luasnya dan memiliki sumber daya alam yang melimpah. Apabila dilihat dari segi prospek usaha juga sangat baik, karena produk olahan makanan ringan ini sangat digemari oleh masyarakat semua kalangan. Jika mendapatkan pelatihan dan 
pendampingan yang efektif, sangat mungkin mampu bersaing dengan produk-produk yang sudah dulu ada di pasar seperti contoh produk makanan olahan khas Batu Malang.

Jika dilihat dari aspek produksi memang masih sangat konvensional, belum mencerminkan proses produksi yang baik. Proses produksi yang sederhana ini dikarenakan mitra masih berorientasi pada pasar yang terbatas, yakni penduduk sekitar Wonosalam. Mindset ini yang perlu dirubah dalam rangka pengembangan usaha mitra, dengan cara memberikan pendampingan yang optimal bagaimana mengembangkan usaha yang baik. Perubahan mindset memang diperlukan waktu agar mitra benar-benar yakin akan potensi usaha untuk dapat berkembang dengan mencakup pasar yang lebih luas.

Manajemen usaha mitra juga jauh dari model pengelolaan usaha yang baik dan benar, mitra masih memandang bahwa usaha ini kecil dan juga tidak memahami bagaimana cara mengelola usaha tersebut dengan baik dan benar. Masih terbatasnya akses informasi dengan pemerintah daerah setempat berdampak pada pengembangan usaha yang dilakukan oleh para mitra. Melalui pendampingan usaha dengan memberikan pemahaman bagaimana membuat laporan keuangan yang baik, bagaimana memasarkan produk UMKM yang tepat, bagaimana mendesain produk melalui Packaging, branding dan labeling, maka akan memiliki daya saing yang tinggi terhadap mitra tersebut.

Alasan memilih kedua mitra tersebut tidak lain karena kedua mitra memiliki kemauan yang sangat kuat dalam meningkatkan kapasitas, serta memiliki upaya meningkatkan keberdayaan masyarakat dengan pelibatan masyarakat untuk bekerja melalui usaha rumahan. Cara yang dilakukan adalah membentuk plasma-plasma sehingga ibu-ibu rumah tangga yang ada di desa tersebut memiliki pendapatan.

Dari hasil pemetaan yang telah dilakukan, diperoleh data terkait persoalan yang dihadapi kedua mitra tersebut, diantaranya : 1) Aspek kualitas sumberdaya manusia yang masih rendah, minimnya pengetahuan wirausaha yang berdampak pada rendahnya produktivitas usaha, ketidakmampuan manajemen usaha terutama dalam hal pencatatan atau pembukuan. 2) Usaha yang digeluti belum memiliki badan hukumyang jelas, minimal legalitas usaha dan terkait dengan perizinan. 3) Rendahnya inovasi produk, hal ini terkait dengan kurangnya penguasaan teknologi, manajemen, pasar, serta informasi. 4) Aspek permodalan menjadi kendala dalam meningkatkan usaha tersebut sehingga kemampuan bersaing dengan produk kompetitor cenderung lebih rendah. 5) Belum ada tenaga pendamping yang mampu memberikan advice dalam rangka pengembangan usaha dan pemberian pelayanan yang dibutuhkan UMKM.

\section{B. METODE PELAKSANAAN KEGIATAN}

Seperti yang telah dijelaskan sebelumnya bahwa persoalan yang dihadapi oleh mitra perlu segera diselesaikan dengan cepat dan tepat melalui berbagai cara sesuai dengan identifikasi masalah yang dihadapi. Untuk itu lebih diperjelas melalui penetapan skala prioritas dalam penentuan solusi pemecahan masalahnya, dan hal ini berupa pelatihan dan pendampingan dengan aspek sebagai berikut: a) Pelatihan dan pendampingan manajemen usaha kecil (tata kelola, perijinan P-IRT, pembukuan dan seterusnya); b) Pelatihan dan pendampingan packaging, branding dan labeling agar menarik dan memiliki daya saing dengan produk lain; c) Pelatihan dan pendampingan akses pemodalan perbankan, untuk memberikan wawasan dalam pengajuan kredit usaha yang berbunga ringan (KUR); d) Pelatihan dan pendampingan aspek pemasaran, untuk memperluas jangkauan pemasaran produk lokal yang marketable.Kegiatan tersebut diperoleh dari hasil pemetaan (mapping) terhadap potensi yang dimiliki oleh kedua mitra serta kualifikasi pendamping, seperti tergambar di bawah, 


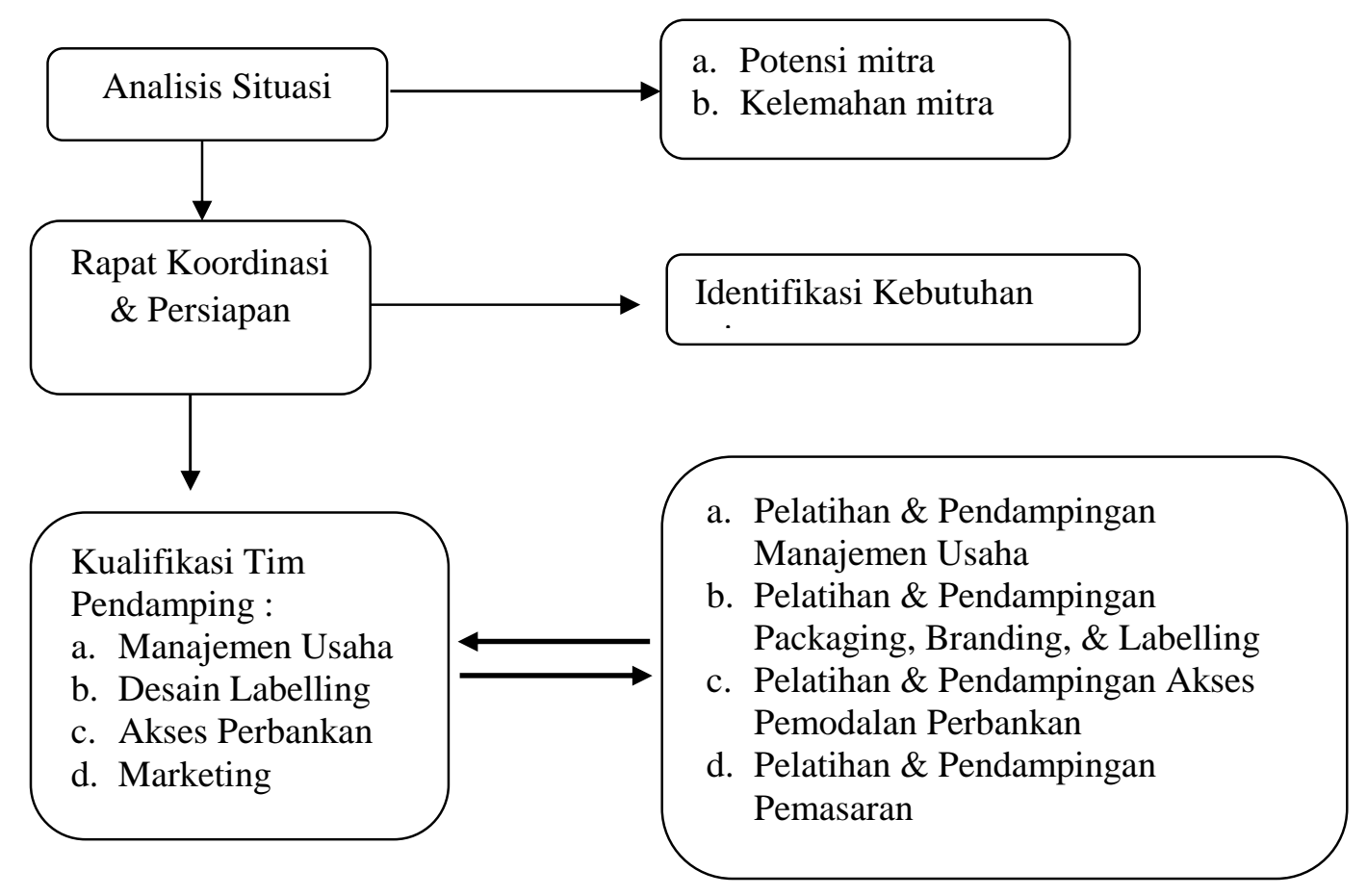

Gambar 1. Penyelesaian persoalan mitra

\section{HASIL KEGIATAN}

Pelaksanaan kegiatan dilakukan melalui beberapa tahapan yaitu:

a. Perencanaan Perencanaan dilakukan sebagai berikut:

1. Melakukan koordinasi dengan LP4M selaku lembaga yang menangani penelitian dan pengabdian;

2. Identifikasi potensi dan kelemahan mitra;

3. Rapat koordinasi dengan tim IbM;

4. Melakukan sosialisasi program IbM terhadap mitra $1 \& 2$ dan pelaku usaha lain yang ada di desa.

b. Pelaksanaan kegiatan

1. Penentuan tim IbM secara internal dan Pelibatan mahasiswa;

2. Pelatihan dan pendampingan manajemen usaha (peningkatan kapasistas produksi, pembukuan, peijinan);

3. Pelatihan dan pendampingan packaging, branding, dan labeling;

4. Pelatihan dan pendampingan akses permodalan;

5. Pelatihan dan pendampingan pemasaran.

c. Observasi dan Evaluasi

Berdasarkan pelaksanaan kegiatan IbM, dilakukan observasi berupa penilaian hasil kegiatan dan tolok ukur keberhasilan program. Namun demikian hasil program masih dalam proses mengingat diperlukan waktu yang cukup untuk membenahi kelemahan mitra. Selanjutnya dilakukan evaluasi hasil pelaksanaan kegiatan IbM waktu berjalan, hambatan dan kendala-kendala apa yang dihadapi untuk mencapai target dan tujuan IbM. Selanjutnya dilakukan langkah strategis untuk memperbaiki dan menyesuaikan pada kondisi yang ada di lapangan. 


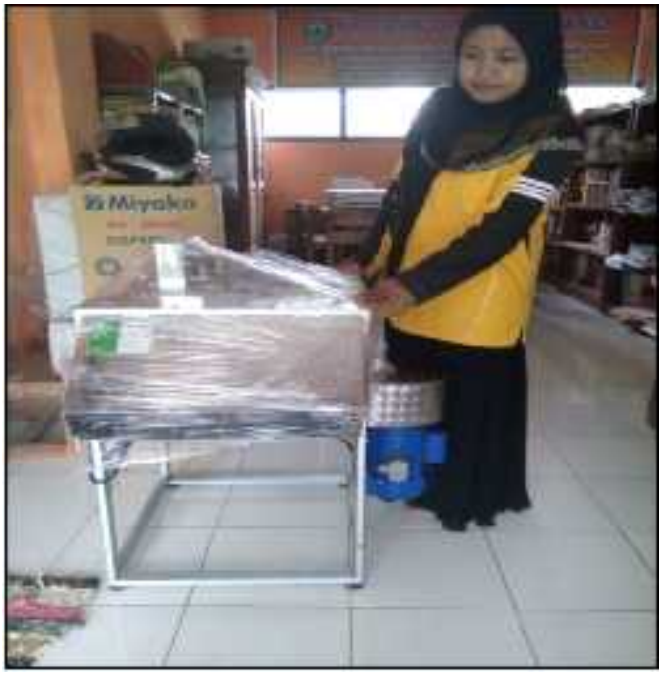

Gambar 2. Alat Produksi

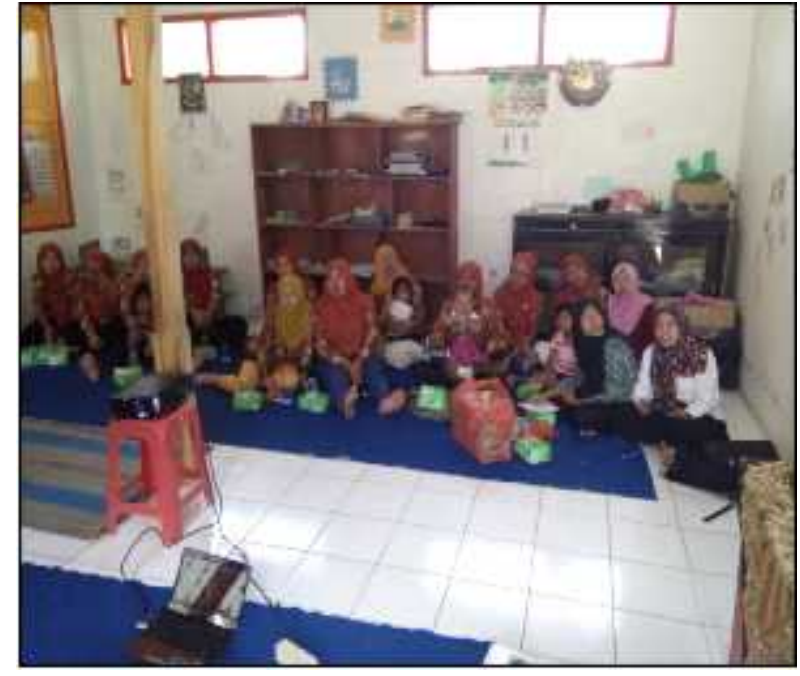

Gambar 3. Suasana pelatiahn

Hasil pelaksanaan kegiatan pendampingan ini telah sesuai seperti apa yang diharapkan, dalam arti aspek kualitas produk, peningkatan kapasitas produksi, kemasan dan desain nya, pemasaran serta menjembatani pada aspek pemodalan. Sehingga dengan demikian sudah terlihat peningkatan dan perubahan yang dilakukan oleh mitra dengan melihat antusias nya dalam kegiatan pelatihan dan kemauan untuk berubah.

Kemauan tersebut berkenaan dengan melakukan pendaftaran perizinan usaha (P-IRT), peningkatan kapasitas produksi dengan meningkatkan jumlah produksinya. Kemauan mitra tersebut direspon juga pada aspek desain packaging, branding dan labeling, mengingat produk yang dihasilkan oleh mitra kurang marketable dari sisi kemasan dan label sehingga tidak mampu menarik konsumen untuk membeli.

Hal tersebut juga terjadi pada aspek pemasaran dan akses pemodalan, yang pada intinya mitra dan masyarakat pada umumnya memiliki kemauan untuk berkembang secara ekonomi dan meningkatkan kapasitas usahanya. Pada aspek produksi terdapat peningkatan kapasitas produksi yang sangat signifikan, yakni yang semula hanya mampu memproduksi $5 \mathrm{~kg}$ dalam sehari, setelah dilakukan pendampingan dan pengadaan alat perajah untuk mempercepat proses penggarisan maka dalam waktu tidak terlalu lama produksi dapat mencapai $10 \mathrm{~kg}$ lebih. Kemampuan peningkatan ini tentunya disesuaikan pula pada keterbatasan sumberdaya manusia yang melakukan proses penggorengan. Sehingga sehari dibatasi sebesar $10 \mathrm{~kg}$ saja, dan itu sudah cukup besar untuk skala mikro.

Pada aspek pemasaran usaha mitra, tim pendamping dari STIE PGRI Dewantara menggunakan jejaring melalui pemasaran komunitas. Bahkan telah didaftarkan keanggotaan pada Mom Preneur Hore (MPH), Permamin, Kewirausahaan BRI, Dekranasda, serta kerjasama dengan showroom UMKM Jombang. Tim IbM belum membidik aspek pemasaran online mengingat mitra sudah memiliki akun jejaring social. Kedepan baru tim IbM akan jembatani media pemasaran secara online. Pada aspek pemodalan, beberapa waktu yang lalu telah diikutkan pelatihan yang diselenggarakan oleh Bank Rakyat Indonesia (BRI). Pada saat pelatihan pemodalan juga disampaikan cara pengajuan kredit ke bank beserta persyaratan yang diperlukan. Pada aspek desain kemasan atau labeling, tim IbM telah membuat desain yang praktis dan menarik agar konsumen tidak ragu lagi membeli produk mitra, dimana telah dicantumkan informasi seperti pada produk-produk makanan lainnya. Informasi produk tersebut diantaranya nomor P-IRT (masih belum keluar/proses), tanggal kadaluwarsa, dan berat atau isi produk. 
Untuk pelaksanaan kegiatan berikutnya adalah pendampingan sekaligus melakukan monitoring pada mitra untuk meningkatkan usahanya tersebut. Mengingat ada empat aspek yang perlu menjadi perhatian dalam pendampingan, maka tim pendamping tetap dikelompokkan sesuai dengan kualifikasi keahlian yang dimiliki, dengan harapan agar fokus pada permasalahan yang ditangani dan dapat segera di lakukan perbaikan pada mitra.

Proses perijinan pengurusan P-IRT masih dilakukan pemantauan sehingga tinggal dimasukkan pada master label yang akan dicetak nanti. Namun demikian sudah dilakukan pencatakan yang cukup banyak, mengingat adanya permintaan pasar yang cukup besar. Tim pendamping juga masih akan melakukan perluasan jaringan pemasaran dengan melakukan optimalisasi jaringan yang dimiliki melalui kerjasama yang telah dilakukan oleh STIE PGRI Dewantara Jombang.

\section{PENUTUP}

Program pendampingan yang dilaksanakan oleh STIE PGRI Dewantara ini adalah pendampingan pada masyarakat pelaku usaha yang berada di desa Carangwulung Kecamatan Wonosalam yang memiliki potensi usaha yang dapat berkembang pesat. Pada prinsipnya mitra sangat concern pada usaha dalam memperbaiki usahanya serta mengembangkannya. Tinggal tim dalam mendampingi diperlukan upaya dan waktu untuk membina mereka agar berdaya saing pada produknya.

Selain itu, disarankan kepada pemerintah setempat untuk memperbaiki akses jalan. Akses jalan menuju mitra menjadi sedikit hambatan bagi tim untuk mendampingi, terutama anggota yang belum tahu medan desa tersebut. Agar para pelaku usaha dapat berdaya saing, maka seyogyanya pemerintah dalam hal ini Dinas Kesahatan Kabupaten Jombang untuk menambah kuota dan waktu pelaksanaan pelatihan dan pendaftaran perijinan usaha (P-IRT).

\section{BIBLIOGRAFI}

Berry, A.E. Rodriquez dan H. Sandeem, 2001, Small and Medium Enterprise Dynamics in Indonesia, Bulletin of Indonesian Economic Studies Vol. 37 (3): 363-384

Primiana, Ina, 2009, Menggerakkan Sektor Riil UKM \& Industri, Alfabeta Bandung

Watterberg, A. at.al., 1999, "A National Snapshot of The Social Impact of Indonesia's Crisis". Bulletin of Indonesian E conomic Studies Vol. 35 No. 3, 145-152 